\title{
Training and Retraining Civil Servants of Home Affairs in Vietnam in Response to the Requirements of International Integration
}

\author{
Cuong Tien Vi \\ Hanoi University of Home Affairs \\ 36 Xuan La, Tay Ho, Hanoi, Vietnam
}

Received: Dec. 24, 2018 Accepted: Jan. 14, 2019 Online published: Jan. 22, 2019

doi:10.5296/ijhrs.v9i1.14085 URL: https://doi.org/10.5296/ijhrs.v9i1.14085

\begin{abstract}
Vietnamese civil servants of Home Affairs play a critical role in advising the Government of Vietnam on policies related to the management and development of the whole public administration system. To improve the performance of officials and cadres, training and retraining programmes for Vietnamese civil servants of Home Affairs need to be designed and delivered in a way that can produce practical and effective outcomes for both participating civil servants and agencies. This study discusses the main features of the contingent of civil servants of Home Affairs in Vietnam and proposes measures to improve the quality and effectiveness in the training and retraining of Vietnamese civil servants of Home Affairs in response to the requirements of the country's public administrative reforms and to the demands of international integration.
\end{abstract}

Keywords: training and retraining, civil servants of home affairs, administrative reforms, reforms of public services, international integration

\section{Introduction}

Civil servants of Home Affairs in Vietnam, in the broad sense, refer to those working in the executive, legislative, and judicial public branches of the state and municipal government and are responsible for a wide range of state and local government administration, education and training, emulation and reward, state management of religions, archiving, and youth development affairs (The Government of Vietnam, 2017a). In the narrow sense, civil servants are employed by the Ministry of Home Affairs and units under the Ministry of Home Affairs, Departments of Home Affairs of provinces and municipalities centrally controlled by the national government, or Offices of Home Affairs at the district, commune or town levels directly under a provincial government (Pham, 2004). 
Due to the critical role of civil servants to the cause of developing the country, the Government and to the people of Vietnam, the training and retraining of this contingent have always been among the top priorities of the Government so that officials and public employees can improve their performance and effectively run and manage public administration (Pham, 2004; Phung, Le, \& Ho, 2013; Tran \& Vu, 2011; UND Vietnam, 2009). Ho Chi Minh, the former Prime Minister and President of Vietnam, places civil servants at the root of all the country's successes and demands Vietnam's Communist Party to consider the training of its officials and cadres as its core assignment (Ho, 1958). He also emphasises that officials and cadres need to be educated and trained to be role-model citizens and officials who can work and serve the masses, their motherland and humanity (Ho, 1949). Recent administrative reforms that have taken place nationwide and the demands and opportunities brought by international integration have further highlighted the strategic role of the training and retraining of civil servants to the development of human resources for Vietnam's public administration. Training and fostering the contingent of civil servants of Home Affairs in particular lie at the heart of public administrative reforms in Vietnam.

The Government of Vietnam has promulgated and enforced different legal documents to guide and renovate the field of training and to improve the knowledge and skills of public servants from the early 1990s. The government's decisions and guidelines serve as steering legal framework for training institutions in determining training objectives, directions, contents and measures in order to improve the quality of the contingent of public servants (United Nations Department of Economic and Social Affairs (DESA), 2004). The main objectives in the training and retraining of Vietnamese civil servants of Home Affairs are to (1) improve the effectiveness of public service and the performance of public employees, (2) improve the quality of human resources for the Home Affairs sector, (3) serve the planning and development of civil servants of Home Affairs, and (4) act as a basis for periodic and annual assessments of the quality and capacity of the human resources of the sector (Phung et al., 2013; Tran \& Vu, 2011; Vietnam Ministry of Home Affairs, 2018). Reports by Vietnam Ministry of Home Affairs (2014) on the three-year implementation of the training plan for officials and civil servants as directed by the Prime Minister of Vietnam in Decision 1374/QĐ-TTg dated 12/8/2011 (The Prime Minister, 2011) show that 100\% of ministries, ministerial branches, and localities have formulated and issued plans on the training and retraining of their officials and civil servants for the 2011-2015 period. Within three years of implementation from 2011, $98 \%$ of officials and civil servants from state to district offices and agencies have been trained to meet the national standards; approximately $71 \%$ of officials and heads of offices in ministries and ministerial agencies and $80 \%$ of those in localities have been trained or retrained in prescribed programmes; and the figures of officials and civil servants from ministries and localities who receive compulsory annual training reach $67 \%$ and 56\% respectively (Vietnam Ministry of Home Affairs, 2014). Training programmes have also been provided for commune officials, with nearly $75 \%$ of those now meeting the national standards; $95 \%$ of civil servants in urban and delta areas have received professional education training at the intermediate level or above while the figure for remote and mountainous areas is $87 \%$ (Vietnam Ministry of Home Affairs, 2014). In-service training programmes for Vietnamese officials and civil servants have focused on leadership, 
management, and administration skills as well as computer and foreign language skills, and are catered to attendees' positions and service duties (DESA, 2004). 70\% of commune-level officials and public servants attend compulsory training yearly while half the non-specialised staff in local communes and wards receive training customised to their assigned tasks (Vietnam Ministry of Home Affairs, 2014).

By 2009, Vietnam's public employment system had undergone drastic policy changes and achieved certain successes such as standardizing and decentralising recruitment and promotion of public employees in the Home Affairs sector, doubling civil service wages, granting greater autonomy to agencies in relation to recruitment and wage policies, and expanding the enrollments in training institutions of public administrations (Hausman, 2010). Following the achievements from previous efforts of civil service reforms, the main tasks of administrative and civil service reforms in the 2011-2020 period as articulated by the Government of Vietnam are to reform and innovate institutional structure; improve the quality of the contingent of officials, cadres, and civil servants; reform wage policies to motivate officials and public servants in performing their public duties to the highest quality and effectiveness; and enhance the quality of administrative and public services (The Government of Vietnam, 2011, 2013). As training and retraining involve planned activities in which skills and knowledge are passed on to trainees to enable them to master the competencies needed for their day-to-day activities (Idris, 2018; Landa, 2018; Motlokoa, Sekantsi \& Monyolo, 2018), receiving quality training and retraining will allow public servants of Home Affairs to be equipped with adequate skills and knowledge to drive the country's reforms and facilitate its integration into the world economy and globalisation of the $21^{\text {st }}$ century.

\section{Home Affairs and Civil Servants of Home Affairs: An Overview}

The Ministry of Home Affairs of Vietnam is a governmental agency whose functions, tasks, power, and organisational structure are defined in the Government's Decree No. 34/2017/ NĐ-CP dated 3/4/2017. The Ministry is responsible for state management of organisational and personnel affairs, including organisational structure of state administration; local government organisations; management of administrative boundaries; state officials and public employees; training and retraining of state administration and state management; non-governmental organisations; emulation and reward; state management of religions; state archives; youth development; and state administration of public services in accordance with state laws (The Government of Vietnam, 2017a).

The Government of Vietnam has issued different guidelines for the recruitment, employment, management as well as organisation of public employees. Specific authorities are assigned to organise and manage recruitment, appraisal, grade promotion, reward and discipline, and training activities (DESA, 2004). Civil servants of Home Affairs are selected by means of the entry-examination method, classified by ranks and grades, and assigned to different line agencies and local authorities of Home Affairs, including the Ministry of Home Affairs and its affiliated units, provincial-level Departments of Home Affairs of provinces and municipalities centrally controlled by the national government, and Offices of Home Affairs 
at the district, commune or town levels directly under a provincial government (Pham, 2004). Recruitment by examination is believed to ensure that only qualified and ethical civil servants are selected to work in state agencies and, as a form of social equality, to encourage and give opportunities to talented individuals to become civil servants (DESA, 2004). Civil servants of Home Affairs are managed by their supervising authorities, which are either the Ministry of Home Affairs, the People's Committees of provinces and municipalities centrally controlled by the state, or the People's Committees of urban districts, towns and cities directly under provinces or centrally-controlled municipalities. These agencies bear the hierarchical and top-down characteristics of the country's political system (Tran \& Vu, 2011).

Civil servants of Home Affairs, on one hand, share common characteristics of Vietnamese civil servants working in the public sector while at the same time possessing distinctive qualities due to the nature of their tasks and functions (Pham, 2004; Tran \& Vu, 2011). Firstly, the most prominent feature of Vietnam's public administration is its close and almost inseparable linkage to the country's political system which is led by the Communist Party of Vietnam. This feature defines the development, including the training and retraining, of state administrative staff in general and civil servants of Home Affairs in particular. To perform the state management and state administration of internal affairs, civil servants of Home Affairs are to assume full responsibilities and duties in political tasks assigned to them by the Government. Reforms in public administration and reforms towards international integration all contribute to serving the political ideology and political service of the country. Secondly, the rule of law is one of the characteristics of Vietnamese public administration, which is reflected in the fact that civil servants are to comply with the Constitution and laws, respect the interests of the State, human rights, and the rights and legitimate interests of offices, organisations and individuals in the process of policy making and offering public service. This rule of law requires civil servants to use the right power and authority in performing their assigned duties, which entails their constant improvement and cultivation of morality, political qualities, professional competence and managerial skills to contribute to the development of the Home Affairs sector and to that of the country. Thirdly, the Ministry of Home Affairs operates in a wide range of domains and branches of state management in state and local authorities, administrative boundaries, non-governmental organisations, emulation and reward, state management of religions, state archives, youth development, and public services in accordance with state laws. Civil servants of Home Affairs, accordingly, are mainly assigned tasks that involve planning and formulating policies on recruitment, staffing, deployment, training and retraining, salaries, emulation of merit, religion management, and clerical archives in order for human resources in administrative agencies and public service delivery units to be effectively managed (The Government of Vietnam, 2017a).

Specific tasks that civil servants of Home Affairs undertake (The Government of Vietnam, 2017a) include

- Guiding and supervising the implementation of training and retraining plans for Vietnamese cadres and civil servants both inland and overseas and for commune-level cadres and civil servants and deputies to the People's Councils at all levels; 
- Using the Government's regulations on the organisation of cadres and civil servants to guide training institutions run by the ministries, ministerial-level agencies, governmental agencies, and People's Committees of centrally-controlled provinces and municipalities;

- Uniformly managing training and retraining programmes for cadres, civil servants, and representatives of the People's Councils across all levels of governance;

- Organising the training and retraining of state management knowledge and skills for officials and employees of Home Affairs and for members of the People's Councils at all levels;

- Allocating, monitoring, and inspecting the implementation of annual training and retraining of cadres and civil servants and reporting outcomes to the Prime Minister;

- Formulating, promulgating, guiding, inspecting, and organising the implementation of human resources master plans; training human resources for the Ministry of Home Affairs at undergraduate and graduate levels.

Given the wide range of tasks assigned to civil servants of Home Affairs, it is essential for the training and retraining of human resources for the Home Affair sector to cover skills and knowledge in relation to (1) state organisations, (2) emulation and reward, (3) archives and (4) religious work associated with specific sectors and localities to meet the requirements of administrative reforms, civil service reforms, and international integration.

According to reports by the Ministry of Home Affairs (Hanoi University of Home Affairs, 2014), as of December 2012, there were 11,786 civil servants working in Home Affairs agencies across the country, of which 3,878 are employed at the state level (32.9\%) and 7,908 at the local level $(67,1 \%)$. Civil servants in local Home Affairs agencies accounted for about two-thirds of the total figure of the sector. The overall quality of human resources in the sector is generally high (Institute of Research and Development on Home Affairs, 2015), with most employees completing a tertiary education (ranging between $41.03 \%$ to $71.6 \%$ across the fields of work) (Figure 1). Due to varying demands of assigned tasks, a larger number of civil servants working on state management of religions have a postgraduate qualification compared with other fields of employment while a significantly large number of civil servants with a professional education diploma are employed to handle archiving tasks. It is also worth noting that many civil servants were employed in other sectors before being rotated or transferred to agencies and offices of Home Affairs. The Ministry of Home Affairs reported the figure as of December 2012 to be around $68.9 \%$, with $32.3 \%$ being civil servants from other industries, $13 \%$ leaders from other agencies, and $23.7 \%$ from non-state offices (Hanoi University of Home Affairs, 2014).

The training and retraining of civil servants of Home Affairs are being implemented in accordance with the Government's Decree No. 101/2017/NĐ-CP dated 1/9/2017 on the training and retraining of officials and civil servants (The Government of Vietnam, 2017b) and the Ministry of Home Affairs' Circular No. 01/2018/TT-BNV dated 8/1/2018 on the training and retraining of civil servants of Home Affairs (Vietnam Ministry of Home Affairs, 2018). Training and retraining programmes mainly focus on improving professional skills and knowledge, managerial skills, and political understanding for civil servants of different positions, ranks, and grades. The crucial question in relation to the design and delivery of 
training and retraining programmes for civil servants of Home Affairs concerns how skill and knowledge gaps can be best addressed so that participants in these programmes can improve their performance that can meet the requirements of international integration (Tran $\& \mathrm{Vu}$, 2011).

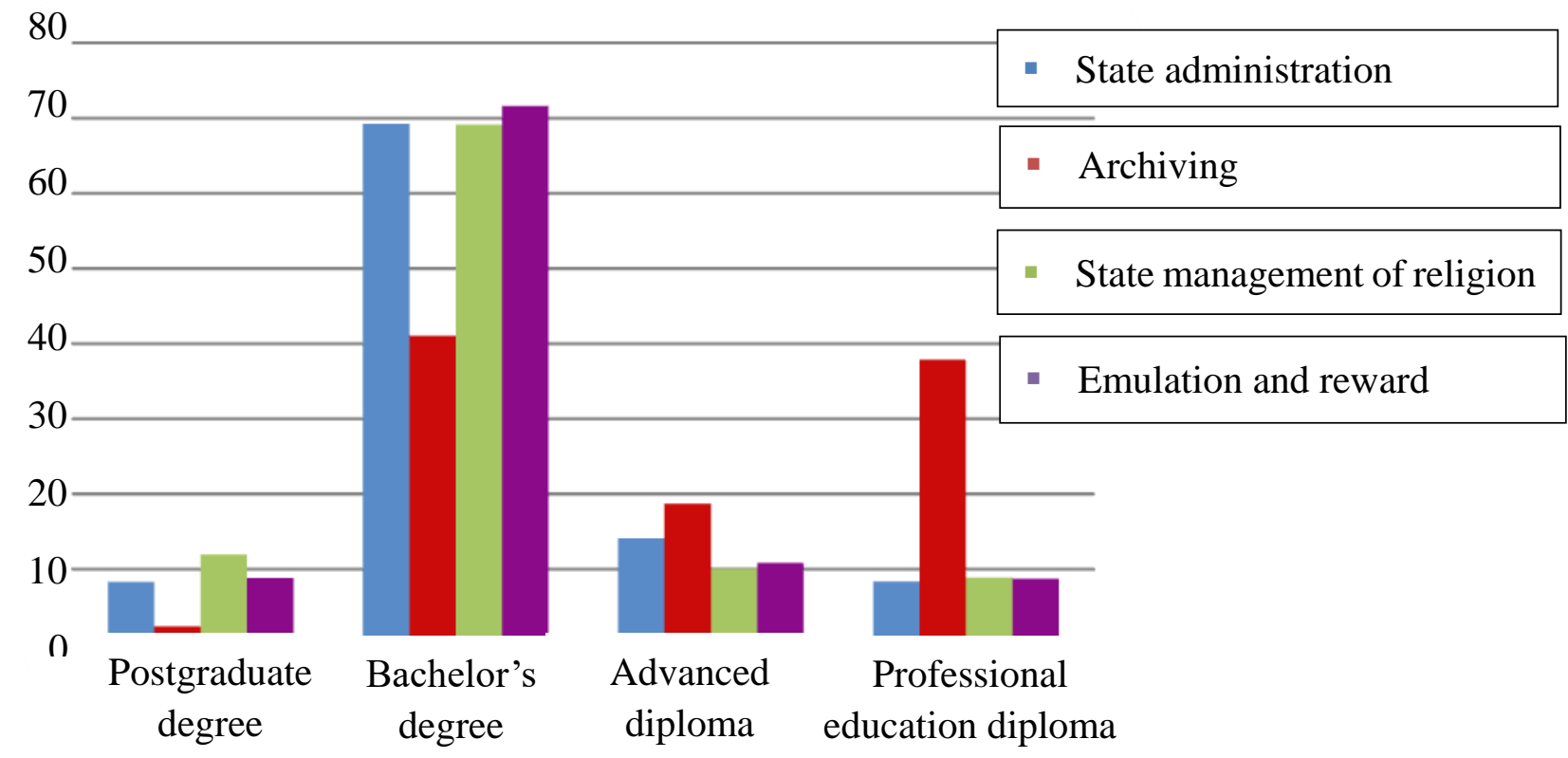

Figure 1. Civil servants of Home Affairs by highest educational qualification (compiled by the author from Institute of Research and Development on Home Affairs, 2015)

\section{Suggested Measures for the Training and Retraining of Vietnamese Civil Servants of Home Affairs in Response to Requirements of International Integration}

While the number of civil servants attending regular training and retraining programmes has increased over the years and the capacity of in-service training schools has been strengthened with more quality trainers, training and retraining activities are argued to be only at an initial stage (DESA, 2004; Vietnam Ministry of Home Affairs Ministerial Inspectorate, 2009). A review of public administration reform by the Government's Steering Committee has found many training and retraining curricula to be of low practicality due to the overemphasis on theories and the lack of practical training of skills relevant to specific jobs and due to some limited physical conditions of training schools (Vietnam Ministry of Home Affairs Ministerial Inspectorate, 2009). The requirement for civil servants to obtain formal qualifications in language, computer and state administration skills has also resulted in cases where public employees try by all means to be eligible for recruitment or promotion examinations in paper while their competencies have not been elevated to the same or similar levels (DESA, 2004). The effectiveness of training and retraining programmes for civil servants of Home Affairs, therefore, must be assessed against the requirements of particular job placement, relevant competency frameworks, performance outcomes, the needs of participating trainees and their host organisations as well as the level of satisfaction of users of public services offered by civil servants and agencies of Home Affairs (Phung et al., 2013; Tran \& Vu, 2011). The following measures are suggested in order to improve the efficiency of the training and retraining of civil servants of Home Affairs in response to the 
requirements of international integration.

Firstly, developing competency frameworks is a strategic imperative to effectively assist the training and retraining of civil servants of Home Affairs. As competency frameworks define the skills, knowledge, attributes, and personality traits of employees at different stages of their career, supervisors and supervising authorities will be able to evaluate their employees' performance, identify the skill and competency gaps, and provide customised training and professional development to support their employees more effectively. The frameworks will also act as a helpful tool in the recruitment and rotation of employees between agencies.

Secondly, when recruiting civil servants, it is of vital importance to accurately assess the organisational needs and define the selection criteria so that the right candidate be selected for the right job in the Home Affairs sector. The recruitment procedure needs to be conducted in a scientific and transparent manner and based on clear sets of criteria and job descriptions in alignment with the requirements of the advertised position and with the expected standards on relevant competency frameworks. This will not only contribute to improving the quality of the contingent of civil servants but also allow for flexible and timely adjustments of staffing in response to the demands of international integration.

Thirdly, the training and retraining of civil servants of Home Affairs are to be grounded on state and ministerial regulations and strategic planning and systemised into a comprehensive and complete procedure. It is necessary to study specific characteristics and needs of Home Affairs agencies to develop effective training and retraining programmes with careful planning, monitoring, and assessment schemes. An effective training programme should not only be cost-effective but also adequately address the skills and knowledge gap while quality aspects at the same time are closely monitored, evaluated and achieved. A competency framework is highly useful in the development and quality assurance process of training and retraining programmes.

Fourthly, an alignment between training outcomes and institutional and individual needs should be considered prior to the admission of trainees. Home Affairs as a governmental agency plays a critical role in consulting and advising the Government of Vietnam in a wide range of domestic affairs. Civil servants working on different fields, therefore, differ in terms of their professional and managerial needs. All the stages of planning, developing and implementing training and retraining programmes are to consider institutional and individual needs so that the right content, trainers, and delivery approaches can be selected. In addition to this, the quality of civil servants of Home Affairs can be greatly improved to meet the demands of globalisation and international integration if training programmes learn from established and well-known education institutions and systems in the region and the world.

Fifthly, it is essential to assess and effectively make use of the contingent of civil servants of Home Affairs. The allocation of officials and cadres to agencies, positions and tasks need to be based on not only the professional qualifications of those employees but also their capacity and strengths. Effective allocation of civil servants of Home Affairs will reduce the pressure on training and retraining, especially in terms of the state's budget, and at the same time motivate public employees at the workplace. 
Last but not least, the evaluation of training and retraining programmes needs to be renovated to remove the superficial formality of the evaluation process. It is necessary to develop a set of tools for post-training evaluation and fostering, and to increase the quantitative assessment criteria to measure the performance of public servants by three factors, namely positions and titles undertake; personal capacity in relation to the capacity of the employment position; and performance of assigned tasks. When programme evaluation and performance assessment can accurately reflect the efforts and the contribution of civil servants, this will create the motivation for them to improve their performance through self-training and participate in the training and fostering of their agencies and units. This will also contribute to improving the quality and efficiency of training and retraining of civil servants of Home Affairs in general, meeting the requirements of administrative reforms, civil service reforms and international integration.

\section{Conclusion}

The training and retraining of civil servants of Home Affairs are part of the strategic agenda in the process of reforming public administration and public service in Vietnam in meeting the requirements of international integration. Identifying the factors affecting the training and retraining of civil servants and having a holistic view on the development of civil servants help to improve the effectiveness of training and retraining programmes from the identification of training needs, planning, selection of trainers to the evaluation of training and retraining outcomes. The ultimate objective of training and fostering is to build and develop a strong body of Vietnamese civil servants capable of meeting the requirements of administrative reform, civil service reform and integration.

\section{References}

Hanoi University of Home Affairs. (2014). Đề án Đào tạo bồi duỡng nhân lực ngành Nội vu (Project on the training and retraining of civil servants of Home Affairs). Hanoi: Hanoi University of Home Affairs.

Hausman, D. (2010). Policy leaps and implementation obstacles: Civil service reform in Vietnam, 1998-2009. New Jersey: Trustees of Princeton University.

Ho, C. M. (1949). Hồ Chí Minh toàn tập (Ho Chi Minh's complete works) (Vol. 5). Reprint, Hanoi: NXB Chính trị Quốc gia (National Politics Publisher), 2000.

Ho, C. M. (1958). Hồ Chí Minh toàn tập (Ho Chi Minh's complete works) (Vol. 5). Reprint, Hanoi: NXB Chính trị Quốc gia (National Politics Publisher), 2000.

Idris, M. (2018). The impact of education and training, work discipline and organizational culture on employee's performance: the study of Disaster Management and Fire Department in Palembang City, Indonesia. International Journal of Human Resource Studies, 8(3), 1-18. https://doi.org/10.5296/ijhrs.v8i3.13013

Institute of Research and Development on Home Affairs. (2015). Báo cáo tổng hơp Dự án "Điều tra khảo sát đánh giá, phân tích nhu cầu và năng lục của đội ngũ cán bộ công chức ngành Nội vụ, đề ra nhũng giải pháp chiến lược để cung cấp nhân sụ và đào tạo chuyên môn, 
nghiệp vu nhằm nâng cao trình độ năng lục của cán bộ công chức ngành Nội vụ” (Report summary on 'Needs analysis and capacity assessment of civil servants of Home Affairs and strategic solutions to enhance the professional skills of civil servants of Home Affairs' Project). Hanoi: Institute of Research and Development on Home Affairs.

Landa, E. (2018). Influence of training on employees performance in public institution in Tanzania. International Journal of Human Resource Studies, 8(2), 324-336. https://doi.org/10.5296/ijhrs.v8i2.13136

Motlokoa, M. E., Sekantsi, L. P., \& Monyolo, R. P. (2018). The impact of training on employees' performance: the case of banking sector in Lesotho. International Journal of Human Resource Studies, 8(2), 16-46. https://doi.org/10.5296/ijhrs.v8i2.12812

Pham, H. T. (2004). Công vụ, công chúc nhà nước (Public services and public servants). Hanoi: Legal Publishing House.

Phung, X. N., Le, Q., \& Ho, N. H. (2013). Innovation and human resource development. Hanoi: Vietnam National University Hanoi Publishing House.

The Government of Vietnam. (2011). Nghị quyết số 30c/NQ-CP ngày 08/11/2011 Ban hành Chuoong trình tổng thể cải cách hành chinh nhà nước giai đoạn 2011-2020 (Resolution No.30c/NQ-CP dated $8 / 11 / 2011$ on the promulgating of the master program on state administration reform in the 2011-2020 period). Hanoi: The Government of Vietnam.

The Government of Vietnam. (2013). Nghị quyết số 76/NQ-CP ngày 13/6/2013 về việc sưa đổi, bổ sung một số điều của Nghi quyết 30c/NQ-CP của Chính phủ (Resolution No.76/NQ-CP dated 13/6/2013 on the amendments of some articles in Resolution No. 30c/NQ-CP by the Government of Vietnam). Hanoi: The Government of Vietnam.

The Government of Vietnam. (2017a). Nghị định số 34/2017/ND-CP ngày 3/4/2017 quy định chức năng, nhiệm vụ, quyền hạn và co cấu tổ chức của Bộ Nội vu (Decree No. 34/2017/ND-CP dated 3/4/2017 defining the functions, tasks, powers and organisational structure of the Ministry of Home Affairs). Hanoi: The Government of Vietnam.

The Government of Vietnam. (2017b). Nghị định số 101/2017/NĐ-CP ngày 01/9/2017 của Chính phủ về đào tạo, bồi duõng cán bộ, công chức, viên chức (Decree No. 101/2017/NĐ-CP dated 1/9/2017 on the training and retraining of officials and civil servants). Hanoi: The Government of Vietnam.

The Prime Minister. (2011). Quyết định số 1374/QĐ-TTg ngày 12/8/2011 của Thủ tuoóng Chính phủ về việc phê duyệt kế hoạch đào tạo, bồi duỡng cán bộ, công chưc giai đoạn 2011-2015 (Decision No. 1374/QĐ-TTg dated 12/8/2011 by the Prime Minister regarding the approval of the training plan for officials and civil servants in the 2011-2015 period). Hanoi: The Prime Minister.

Tran, T. T., \& Vu, H. N. (2011). Giáo trình Quản lý nguồn nhân lực trong tổ chức công (Course notes on human resource management in public organisations). Hanoi: National Economics University Publishing House. 
UND Vietnam. (2009). Research report on institutional reforms in public administration in Vietnam. Hanoi: UND Vietnam.

United Nations Department of Economic and Social Affairs (DESA). (2004). The Socialist Republic Of Viet Nam public administration: Country profile. New York: Division for Public Administration and Development Management (DPADM).

Vietnam Ministry of Home Affairs. (2014). Báo cáo số 2880/BC-BNV ngày 31/7/2014, kết quả 3 năm thực hiện Quyết định số 1374/QĐ-TTg ngày 12/8/2011 của Thủ tướng Chính phủ về việc phê duyệt kế hoạch đào tạo, bồi dưỡng cán bộ, công chức giai đoạn 2011-2015 (Report No. 2880/BC-BNV dated $31 / 7 / 2014$ on the three-year implementation of Decision No. 1374/QĐ-TTg dated 12/8/2011 by the Prime Minister regarding the approval of the training plan for officials and civil servants in the 2011-2015 period). Hanoi: Vietnam Ministry of Home Affairs.

Vietnam Ministry of Home Affairs. (2018). Thông tư số 01/2018/TT-BNV ngày 08/01/2018 của Bộ Nội vụ về hướng dẫn thực hiện một số điều của Nghị định số101/2017/NĐ-CP ngày 01/9/2017 của Chính phủ về đào tạo, bồi dưỡng cán bộ, công chức, viên chức (Circular No. 01/2018/TT-BNV dated 8/1/2018 on guidelines for the articles in Decree No. $101 / 2017 / \mathrm{NĐ}-\mathrm{CP}$ by the Government on the training and retraining of officials and civil servants). Hanoi: Vietnam Ministry of Home Affairs.

Vietnam Ministry of Home Affairs Ministerial Inspectorate. (2009). Strengthening the home affairs inspectorate capacity to the year 2014: POSCIS component project document. Hanoi: Vietnam Ministry of Home Affairs Ministerial Inspectorate.

\section{Copyright Disclaimer}

Copyright for this article is retained by the author(s), with first publication rights granted to the journal.

This is an open-access article distributed under the terms and conditions of the Creative Commons Attribution license (http://creativecommons.org/licenses/by/4.0/). 